\title{
Renal Pelvis and Ureter Cancer pM1 TNM
} Finding v8

National Cancer Institute

\section{Source}

National Cancer Institute. Renal Pelvis and Ureter Cancer pM1 TNM Finding v8. NCI

Thesaurus. Code C140338.

Renal pelvis and ureter cancer with distant metastasis. (from AJCC 8th Ed.) 